\title{
Cutaneous Manifestations in HIV Infected Libyan Patients
}

\author{
Nabil A. ALJEHAWI, Omran O. BUGREIN, Azza GREW, Gamal Ahmed DUWEB \\ Dermatology and Community Medical Departments, Faculty of Medicine, Benghazi University, Benghazi, Libya \\ *Correspondence: Gamal Ahmed Duweb, Dermatology Department, Faculty of Medicine, \\ Benghazi University, Benghazi, Libya, E-mail: drduweb@gmail.com
}

UDC 616.5:[616.988:578.828

\begin{abstract}
Cutaneous manifestations of human immunodeficiency virus (HIV) disease may result from HIV infection itself, or from opportunistic disorders secondary to the declined immunocompetence due to the disease. A total of $220 \mathrm{HIV}$ positive patients, treated in the Benghazi Center of Infectious Diseases and Immunology over a period of 14 years (January 2003 to November 2016), were included in a retrospective study. The patients' age ranged from 7 to 46 years. The study was conducted by reviewing the patients' records using the management information system (MIS). Statistical analysis of the data was carried out by the t-test and Chi square test. Among the studied patients, 119 (54.1\%) were males and 101 (45.9\%) were females, and most of them (78.6\%) were 10 - 19 years of age. The predominant mode of transmission was parenteral transmission, in $95 \%$ of patients, and positive family history was observed in $12 \%$ of patients. Among the total number of visits to dermatologists, $93 \%$ of patients had a single disease. Of the total number of skin diseases diagnosed during the visits, parasitic infestations were seen in 92 patients (21.0\%), eczematous and related disorders in 78 patients (17.8\%), viral infections in 71 patients (16.2\%), bacterial infections in 41 patients $(9.3 \%)$, and fungal infections in 35 patients (7.9\%). Dermatophyte infections were the most common fungal infections recorded in 19 patients (4.3\%), followed by Candida infection in 11 patients (2.5\%). Warts were found in $5.9 \%$ of viral infections, followed by herpes zoster (4.1\%). HIV positive patients should be examined for skin disorders, because early diagnosis and management of such problems improves the quality of life in these patients.
\end{abstract}

Key words: HIV; HIV Infections; AIDS-Related Opportunistic Infections; Retrospective Studies; Skin Diseases; Libya

\section{Introduction}

Acquired immune deficiency syndrome (AIDS), or acquired immunodeficiency, is a disease of the human Immune system caused by the human immunodeficiency virus(HIV) $(1,2,3)$. About $39-46$ million people in the world are currently living with HIV/AIDS, and HIV infection is among the main health problems worldwide. Since 1981, when the first reports about AIDS were published in the medical literature, skin and mucocutaneous diseases have played an important role in the clinical diagnosis of acquired immunodeficiency. Opportunistic infections of the skin and oral cavity, such as herpes simplex and candidiasis, were noted to be clinical markers of acquired immunodeficiency (2). Candida albicans infection, presenting as extensive oral thrush or recalcitrant monilial diaper dermatitis, is the most common and often the first manifestation of pediatric HIV infection.
Bacterial infections, including severe forms of staphylococcal impetigo, ecthyma and furuncles, are also common (3). Extensive molluscum contagiosum, herpes simplex infection and plane warts are also common with lesions which are more widely distributed and very difficult to treat.

Non infectious/inflammatory dermatosis like seborrheic eczema and Kaposi's sarcoma, which are common in adults in whom they become more widespread and refractory to treatment as CD4+ T-cell count declines, are exceptional in children. Pruritic papular eruption (PPE) of HIV/AIDS is common in both adults and children with marked depletion of CD4+ T-lymphocytes (4).

Skin diseases are considered a major health problem among HIV positive patients presenting with a variety of dermatologic manifestations. In this study, our aim was to assess epidemiological and clinical cutaneous manifestations in Libyan HIV positive patients. 
Table 1. Age distribution of patients

\begin{tabular}{ccc}
$\%$ & No & Age groups/years \\
0.5 & 1 & $9-0$ \\
\hline 78.6 & 173 & $19-10$ \\
\hline 15.5 & 34 & $29-20$ \\
\hline 2.7 & 6 & $39-30$ \\
\hline 2.7 & 6 & $49-40$ \\
\hline
\end{tabular}

\section{Material and Methods}

This retrospective study included 220 HIV positive Libyan patients who visited the Dermatology Clinic of the Benghazi Center of Infectious Diseases and Immunology (BCIDI) on one or more occasions with different skin lesions over a period of 14 years (January 2003 to November 2016). The patients' age ranged from 7 to 46 years. The study was conducted by reviewing the patients' medical records and their data were collected by using the Management Information System (MIS). The records were screened for dermatological findings by thorough examination of patients' age, sex, residence, family history and date of HIV diagnosis, including the number of visits to a dermatologist, clinical findings, and diagnosis. The data were collected and processed according to a previously prepared procedure. Statistical analysis of the data was carried out using the Statistical Package for the Social Sciences (SPSS) (version 12) software and analyzed using the t- test and Chi square test.

\section{Results}

Among the 220 HIV positive patients included in this study, 119 patients (54.1\%) were

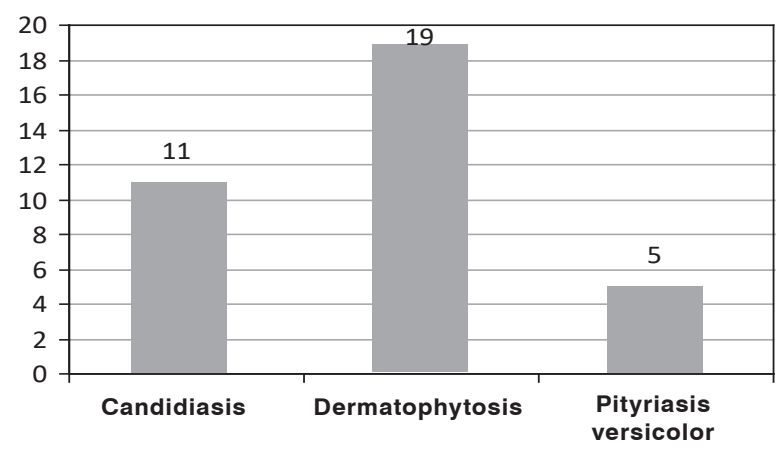

Figure 1. Fungal infections in the study sample males and 101 (45.9\%) were females. Their age ranged from 7 to 46 years (mean 16.5 years). A total of 189 patients (86\%) were residents of Benghazi, whereas 31 patients (14\%) were residents of rural areas. Positive family history for HIV was found in $12 \%$ of cases $(5 \%$ were parents, $4.1 \%$ were sons or daughters, $1.8 \%$ were siblings and only in $0.9 \%$ there were more than one infected member). The age of onset was from 0 to 5 years of age in $66.3 \%$ of cases (146 patients), in $18.6 \%$ between the age of 6 and 10 years, and in the remaining cases the onset was at older age. The most affected age group was from 10 to 19 years, which accounted for $78.6 \%$ of patients (173 patients); the next most affected group accounted for $15.5 \%$ (34 patients) aged from 20 - 29 years; the older age groups were less frequently affected (Table 1).

The predominant mode of HIV transmission in our patients was parenteral transmission, found in 209 patients (95\%), from child to mother $(4.5 \%)$ where cracks in the nipple of lactating mother and the presence of oral erosions or ulcers in the child may facilitate the transmission of HIV by breast feeding. Ninety percent of patients were co-infected with at least one viral infection, and about $62.7 \%$ of them were co-infected with more

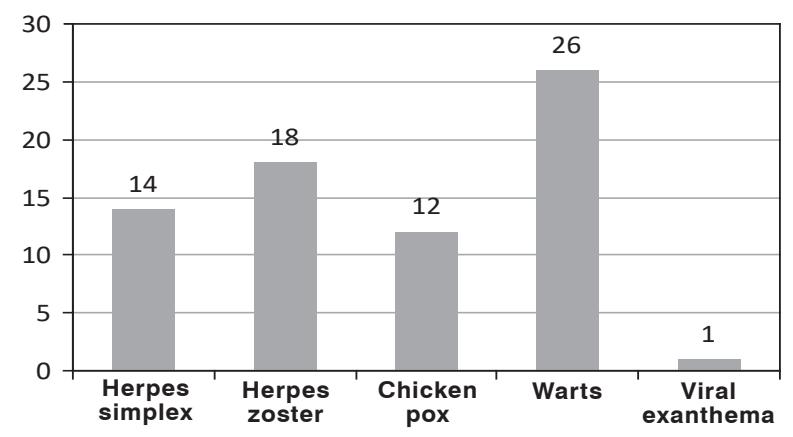

Figure 2. Viral infections in the study sample 
Table 2. Common skin disorders in the study sample

\begin{tabular}{lcccc} 
Skin disorder & $\begin{array}{c}\text { As a single skin dis- } \\
\text { order }\end{array}$ & $\begin{array}{c}\text { With another skin } \\
\text { disorder }\end{array}$ & All observations & \% from all complaints \\
Parasitic infestations & 86 & 6 & 92 & $21.0 \%$ \\
\hline Eczema and related disorders & 68 & 10 & 78 & $17.8 \%$ \\
\hline Viral infections & 60 & 11 & 71 & $16.2 \%$ \\
\hline Bacterial infections & 40 & 1 & 41 & $9.3 \%$ \\
\hline Fungal infections & 30 & 5 & 35 & $7.9 \%$ \\
\hline Total & 284 & 33 & 317 & $72.2 \%$ \\
\hline
\end{tabular}

than one viral agent. The most prevalent infection was cytomegalovirus found in $80.9 \%$, followed by hepatitis $C$ virus (46.8\%), hepatitis $B$ virus (22\%), and uncommonly by toxoplasmosis $(10 \%)$ and rubella only in $3.6 \%$. The number of visits to dermatologists during this period was 408 (1.86 per patient) and the total number of complaints was 439 (2 per patient). Among the total number of visits to dermatologists, $93 \%$ of patients had a single disease, $6.1 \%$ had two diseases, and only $0.7 \%$ had three diseases.

Of the total number of skin diseases diagnosed during visits, parasitic infestations were seen in 92 patients $(21.0 \%)$, eczematous and related disorders in 78 patients (17.8\%), viral infections in 71 patients (16.2\%), bacterial infections in 41 patients $(9.3 \%)$, and fungal infections in 35 patients (7.9\%) (Table 2). Dermatophyte infections were the most common fungal infections recorded in 19 patients (4.3\%), followed by Candida infections in 11

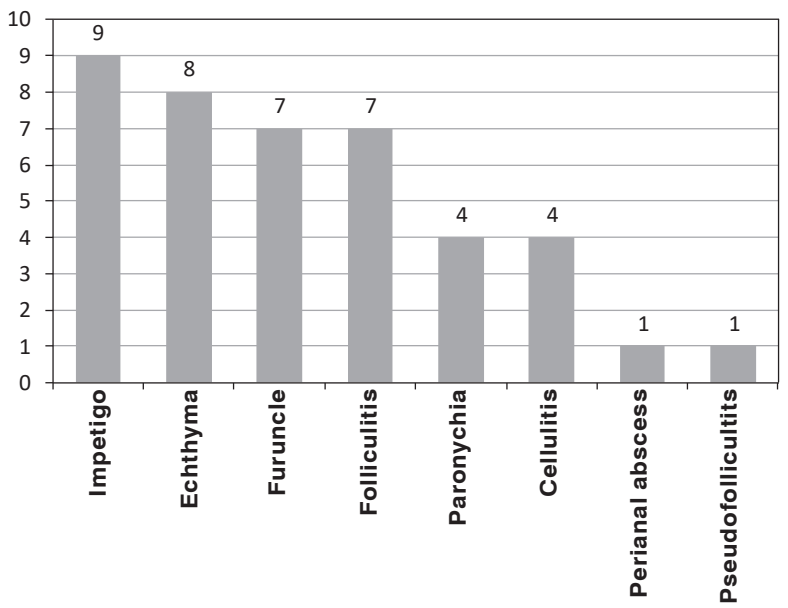

Figure 3. Bacterial infections in the study sample patients (2.5\%) (Figure 1). Warts accounted for $5.9 \%$ of viral infections, followed by herpes zoster (4.1\%) (Figure 2). There were 41 patients with bacterial infections, $9(2.1 \%)$ with impetigo, followed by ecthyma in $8(1.8 \%)$, and furuncle in 7 patients (1.6\%) (Figure 3). Eczematous disorders accounted for $11.5 \%$ of all complaints; atopic dermatitis, photodermatitis and seborrheic dermatitis were the most common disorders, found in 16 (3.6\%), $9(2.1 \%)$ and $8(1.8 \%)$ patients, respectively (Figure 4). Insect bites and scabies were seen in 58 and 31 patients $(13.2 \%, 7.1 \%)$, respectively. The total number of cases with other skin dermatoses was 122 patients (27.8\%), including pityriasis alba in 40 patients and acne vulgaris and xerosis in 17 patients each (Table 3).

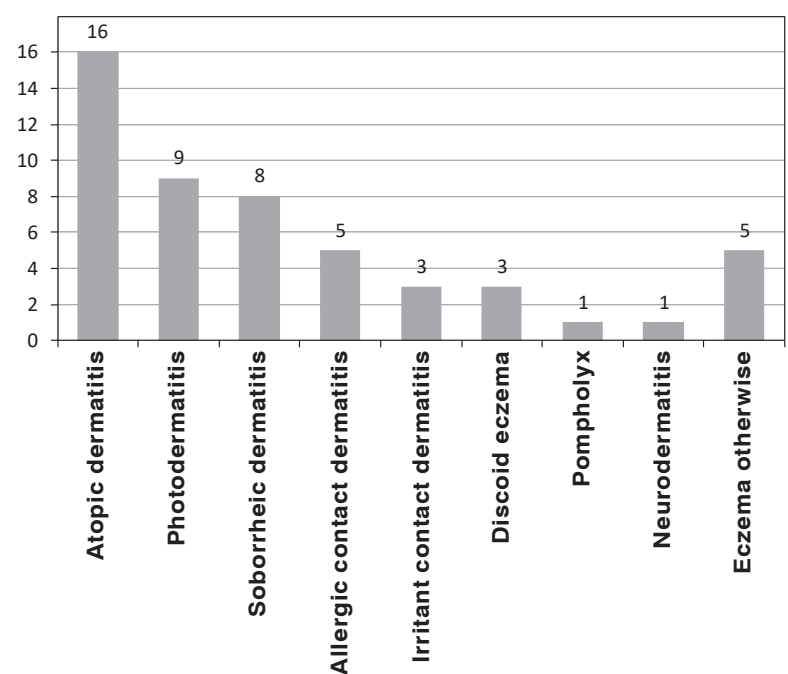

Figure 4. Eczematous dermatoses in the study sample 
Table 3. Other skin disorders in the study sample

\begin{tabular}{|c|c|c|c|c|}
\hline Skin disorder & $\begin{array}{l}\text { As a single skin } \\
\text { disorder }\end{array}$ & $\begin{array}{l}\text { With another skin } \\
\text { disorder }\end{array}$ & All observations & $\%$ from all complaints \\
\hline Acne vulgaris & 15 & 2 & 17 & $3.9 \%$ \\
\hline Xerosis & 11 & 6 & 17 & $3.9 \%$ \\
\hline Aphthous ulcer & 7 & 1 & 8 & $1.8 \%$ \\
\hline Angular stomatits & 5 & 2 & 7 & $1.6 \%$ \\
\hline Cheilitis & 4 & 1 & 5 & $1.15 \%$ \\
\hline Dandruff & 5 & 0 & 5 & $1.15 \%$ \\
\hline Alopecia & 4 & 0 & 4 & $0.9 \%$ \\
\hline Psoriasis vulgaris & 4 & 0 & 4 & $0.9 \%$ \\
\hline Keratosis pilaris & 4 & 2 & 6 & $1.4 \%$ \\
\hline Pityriasis rosea & 2 & 0 & 2 & $0.5 \%$ \\
\hline Pityriasis amiantacea & 1 & 1 & 2 & $0.5 \%$ \\
\hline Acneiform eruption & 1 & 0 & 1 & $0.2 \%$ \\
\hline Callosities & 1 & 0 & 1 & $0.2 \%$ \\
\hline Chilblains & 1 & 0 & 1 & $0.2 \%$ \\
\hline Ichthyosis vulgaris & 1 & 0 & 1 & $0.2 \%$ \\
\hline Necrobiosis lipoidica diabeticorum & 1 & 0 & 1 & $0.2 \%$ \\
\hline Pityriasis alba & 29 & 11 & 40 & $9.1 \%$ \\
\hline Total & 96 & 26 & 122 & $27.8 \%$ \\
\hline
\end{tabular}

\section{Discussion}

Cutaneous disorders may be the initial sign of HIV-related immunosuppression. Recognition of HIV-related skin changes may lead to the diagnosis of HIV infection in the early stages, providing timely initiation of appropriate antiretroviral therapy.

A variety of neoplastic, infectious, and noninfectious diseases may present with cutaneous manifestations throughout the course of HIV infection. The manifestations may occur more frequently than in persons without HIV infection and may be less responsive to usual treatment modalities (5). There is evidence in literature pertaining to the fact that prevalence and pattern of skin diseases vary from region to region $(6,7,8)$. For instance, the prevalence rates of dermatologic problems established in Tanzania, Cameron, Thailand and Zambia were $41.7 \%$, 68.8\%, 95\%, and $98.3 \%$, respectively $(8,9,10,11)$.
In our study, at least one skin lesion was detected in $93 \%$ of patients and this is consistent with other studies, including Pitche et al. (82.5\%), Sanadaj city in Iran (94.3\%), Jeffrey et al. in $86 \%$ of their patients, whereas a South Western France study showed that it was somewhat lower $(65.3 \%)(12,13,14)$. Results of the present study showed that 119 patients $(54.1 \%)$ were males and 101 patients $(45.9 \%)$ were females, which is relatively similar to another study in the tertiary care hospital in atribal (Bastar) region of Chhattisgarh in India, where of 137 patients, $83(60.58 \%)$ were males and $54(39.41 \%)$ were females (15).

Our patients were between 7 and 46 years of age (mean 16.5 years), and the most affected age group was from 10 to 19 years, accounting for $78.6 \%$ of all patients. This finding did not correlate with the findings of Bravo et al. (2006) who found that the most affected 
age was the sexually active age group from 30 to 39 years (51\%) (16). Also, the age of HIV onset in our patients was between the age of 0 - 5 years in $66.3 \%$ of cases (146 patients), $18.6 \%$ between the age of 6 - 10 years, and the remaining fewer cases were found at older ages. This may be explained by the fact that the predominant mode of HIV transmission in our patients was by parenteral abuse (95\%), while they were admitted to Child Hospital in 1998, while the others were either mothers who got the infection from their children or through vertical transmission from mother to child (4.5\%, 0.5\%, respectively); however, other studies reported that the modes of transmission were by homosexual partners in $35.3 \%$, intravenous drug use in $27.8 \%$, and heterosexual partners in $24.4 \%$ of cases (14).

Among the total number of skin diseases diagnosed during the visits, parasitic infestations were found in 92 patients (21.0\%), eczematous and related disorders in 78 patients (17.8\%), viral infections in 71 patients $(16.2 \%)$, bacterial infections in 41 patients $(9.3 \%)$, and fungal infections in 35 patients (7.9\%). Similar to Eichmann's study, eczema was common in our patients (17). Viral, bacterial and fungal infections were common in our study, which is consistent with other studies, where fungal, viral, bacterial infections and neoplasms were the most common findings $(18,19)$.

In comparison to other studies, oral candidiasis was observed only in $2.5 \%$ of our patients, whereas in other studies it accounts for $34.3 \%$ and $54.17 \%$ in Sivayathorn and Wiwanitkit reports, respectively $(20,21)$. Dermatophytosis accounted for $4.3 \%$ from all complaints, and this is not consistent with a study conducted in USA accounting for 34\% of cases (11).

Regarding viral infections in the present study, warts were the most common accounting for $37 \%$ of all viral infections $(5.9 \%$ from all complaints). This was not in line with the results of the study carried out at the Phramongkutkloa Hospital Skin Clinic, Bangkok, which showed herpes zoster as the most common viral infection (48.2\%) of all viral infections and no cases of warts were reported. In our study, herpes zoster was observed only in $4.1 \%$, which is very much lower than Sivayathor's report in which herpes zoster was found in $16.3 \%$ of cases (20). Also, herpes simplex was observed only in $3.2 \%$, which is not consistent with the same study report where herpes simplex was found in $14.9 \%$ of cases (20). Although our and the other study reported low frequency of seborrheic dermatitis found in $1.8 \%$ and $4.7 \%$, respectively, other international data reported higher percentage of seborrheic dermatitis $(21 \%$ and $46.6 \%$, respectively) $(20,21)$.

\section{Abbreviations} drome

AIDS - acquired immune deficiency syn-

HIV - human immunodeficiency virus

PPE - pruritic papular eruption

BCIDI - Benghazi Center of Infectious

Diseases and Immunology

MIS - Management Information System

SPSS - Statistical Package for the Social

Sciences

\section{References}

1. Sepkowitz KA. AIDS-the first 20 years. $\mathbf{N}$ Engl J Med. 2001;344(23):1764-72.

2. Weiss RA. How does HIV cause AIDS? Science. 1993;260(5112):1273-9.

3. Cecil RS, Wyngaarden JB, Smith LH. Textbook of medicine. Philadelphia: Saunders; 1988. p. 1523, 1799.

4. Mgonda YM, Urassa WK, Lyamuya EF, Pallangyo KJ, Mbena EC. The clinical and immunological characteristics of pruritic papular eruption of HIV disease: experience from Dar es Salaam, Tanzania. Tanzania Medical Journal. 2001;16:1-4.

5. Cedeno-Laurent F, Gómez-Flores M, Mendez N, Ancer-Rodríguez J, Bryant JL, Gaspari AA, et al. New insights into HIV-1-primary skin disorders. J Int AIDS Soc. 2011;14:5.

6. Yazdanpanah Y, Chêne G, Losina E, Goldie SJ, Merchadou LD, Alfandari S, et al. Incidence of primary opportunistic infections in two human immunodeficiency virus-infected French clinical cohorts. Int $\mathrm{J}$ Epidemiol. 2001;30(4):864-71.

7. Stein DS, Korvick JA, Vermund SH. CD4+ lymphocyte cell enumeration for prediction of clinical course of human immunodeficiency virus disease: a review. J Infect Dis. 1992;165(2):352-63.

8. Pitche P, Tchangaï-Walla K, Napo-Koura G, Mijiyawa M, Agbere A, Tatagan A. Prevalence of skin manifestations in AIDS patients in the Lome-Tkom University Hospital (Togo). Sante. 1995;5(6):349-52.

9. Muhammad B, Eligius L, Mugusi F, Aris E, Chale S, Magao $\mathrm{P}$, et al. The prevalence and pattern of skin 
diseases in relation to CD4 counts among HIV-infected police officers in Dar es Salaam. Trop Doct. 2003;33(1):44-8.

10. Mbuagbaw J, Eyong I, Alemnji G, Mpoudi N, SameEkobo A. Patterns of skin manifestations and their relationships with CD4 counts among HIV/AIDS patients in Cameroon. Int J Dermatol. 2006;45(3):280-4.

11. Hira SK, Wadhawan D, Kamanga J, Kavindele D, Macuacua R, Patil PS, et al. Cutaneous manifestations of human immunodeficiency virus in Lusaka, Zambia. J Am Acad Dermatol. 1988;19(3):451-7.

12. Rad F, Ghaderi E, Moradi G, Mafakheri L. The relationship between skin manifestations and CD4 counts among HIV positive patients. Pak J Med Sci. 2008;24(1):114-7.

13. Samet JH, Muz P, Cabral P, Jhamb K, Suwanchinda A, Freedberg KA. Dermatological manifestations in HIV-infected patients. A primary care perspective. Mayo Clin Proc. 1999;74(7):658-60.

14. Spira R, Mignard M, Doutre MS, Morlat P, Dabis F. Prevalence of cutaneous disorders in a population of HIV-infected patients. Southwestern France, 1996. Groupe d'Epidemiologie Clinique du SIDA en Aquitaine. Arch Dermatol. 1998;134(10):1208-12.

15. Singh $H$, Singh $P$, Tiwari $P$, Dey V, Dulhani N, Singh A. Dermatological manifestations in HIV-infected patients at a tertiary care hospital in a tribal (Bastar) region of Chhattsgarh, India. Indian J Dermatol 2009;54(4):338-41.

16. Bravo IM, Correnti M, Escalona L, Perrone M, Brito A, Tovar V, et al. Prevalence of oral lesions in HIV patients related to CD4 cell count and viral load in a Venezuelan population. Med Oral Patol Oral Cir Bucal. 2006;11(1):E33-9.

17. Samet JH, Muz $P$, Cabral $P$, Jhamb K, Suwanchinda A, Freedberg KA. Dermatologic manifestations in HIV-infected patients: a primary care perspective. Mayo Clin Proc. 1999;74(7):658-60. Same as ref. 13

18. Spira R, Mignard M, Doutre MS, Morlat P, Dabis F. Prevalence of cutaneous disorders in a population of HIV-infected patients. Southwestern France, 1996. Groupe d'Epidemiologie Clinique du SIDA en Aquitaine. Arch Dermatol. 1998;134(10):1290-2. Same as ref 14.

19. Eichmann A. Skin manifestations in patients with HIV infection. Z Hautkr. 1990;65(7):640-4.

20. Sivayathorn A, Srihra B, Leesanguankul W. Prevalence of skin disease in patients infected with human immunodeficiency virus in Bangkok, Thailand. Ann Acad Med Singapore. 1995;24(4):528-33.

21. Wiwanitkit V. Prevalence of dermatological disorders in Thai HIV-infected patients correlated with different CD4 lymphocyte count statuses: a note on 120 cases. Int J Dermatol. 2004;43(4):265-8.

\section{Kutane manifestacije kod libijskih pacijenata inficiranih HIV-om}

\section{Sažetak}

Kutane manifestacije u vezi sa infekcijom virusom humane imunodeficijencije (HIV) mogu biti posledica same infekcije HIV-om, ili sekundarnih oportunističkih infekcija nastalih usled smanjene imunokompetentnosti pacijenta. U retrospektivnu studiju uključeno je ukupno 220 pacijenata pozitivnih na HIV, lečenih u Bengazijskom centru za infektivne bolesti i imunologiju u periodu od 14 godina (od januara 2003. do novembra 2016. godine). Starost pacijenata kretala se od sedam do 46 godina. Studija je sprovedena analizom istorija bolesti pacijenata koristeći menadžmenski informacioni sistem (MIS). Statistička analiza podataka izvedena je primenom t-testa i hi-kvadrat testa. Među ispitivanim pacijentima, bilo je 119 (54,1\%) muškaraca i 101 (45,9\%) žena, a većina njih $(78,6 \%)$ bila je u starosnoj grupi od 10 do 19 godina. Glavni put prenosa HIV-a bio je parenteralni, kod 95\% pacijenata, a pozitivna porodična istorija zabeležena je kod $12 \%$ pacijenata. Od ukupnog broja pacijenata koji su bili na pregledu kod dermatologa, 93\% pacijenata imalo je samo jednu bolest. Od ukupnog broja kožnih bolesti dijagnostikovanih tokom pregleda, parazitsku infekciju imalo je 92 bolesnika (21\%); ekcem ili neku srodnu bolest imalo je 78 pacijenata (17,8\%); virusnu infekciju imao je 71 pacijent (16,2\%); bakterijsku infekciju 41 pacijent $(9,3 \%)$ i gljivičnu infekciju 35 pacijenata $(7,9 \%)$. Dermatofitne infekcije bile su najčešće gljivične infekcije zabeležene kod 19 pacijenata (4,3\%), zatim kandida kod 11 pacijenata $(2,5 \%)$. Virusne bradavice su pronađene kod 5,9\% infekcija, a zatim herpes zoster (4,1\%). Potrebno je da pacijente pozitivne na HIV pregleda dermatolog jer rana dijagnoza i lečenje kožnih bolesti poboljšava kvalitet života ovih pacijenata.

Ključne reči: HIV; HIV infekcije; Oportunističke infekcije vezane za sindrom stečene imunodeficijencije; Retrospektivne studije; Kožne bolesti; Libija 